\title{
Nuclear Factor NF-kappa-B p50 Subunit
}

National Cancer Institute

\section{Source}

National Cancer Institute. Nuclear Factor NF-kappa-B p50 Subunit. NCI Thesaurus. Code C131127.

Nuclear factor NF-kappa-B p50 subunit (433 aa, $\sim 48 \mathrm{kDa}$ ) is encoded by the human NFKB1 gene. This protein is involved in both transcriptional regulation and signal transduction. 